\title{
The Suzuki cross-coupling reaction: a powerful tool for the attachment of organometallic 'NCN'-pincer units to biological scaffolds ${ }^{\text {is }}$
}

\author{
Gabriela Guillena $^{\mathrm{a}}$, Cornelis A. Kruithof ${ }^{\mathrm{a}}$, Miguel A. Casado ${ }^{\mathrm{a}}$, Maarten R. Egmond ${ }^{\mathrm{b}}$, \\ Gerard van Koten ${ }^{a, *}$ \\ ${ }^{a}$ Department of Metal-Mediated Synthesis, Debye Institute, Utrecht University, Padualaan 8, 3584 CH Utrecht, The Netherlands \\ ${ }^{\mathrm{b}}$ Department of Enzymology and Protein Engineering, C.B.L.E., Utrecht University, Padualaan 8, 3584 CH Utrecht, The Netherlands
}

Received 3 September 2002

\begin{abstract}
Platinum(II) and palladium(II)-NCN $\left\{\mathrm{NCN}\right.$ is the terdentate coordinating monoanionic 'pincer' ligand $\left[\mathrm{C}_{6} \mathrm{H}_{3}\left(\mathrm{CH}_{2} \mathrm{NMe}_{2}\right)_{2}\right.$ $\left.2,6]^{-}\right\}$complexes have been covalently bonded via their para-position to both the $\alpha$-carbon of an $\alpha$-amino acid and to the $\gamma$-position of an alkyl phosphonate by means of Suzuki cross-coupling reactions. The resulting platinum(II) complexes can be used as biomarkers, while the palladium(II) analogs are active Lewis-acid catalysts. Both the pincer-metal substituted $\alpha$-amino acid and phosphonate can be used to introduce these organometallic units in biomolecules such as proteins or enzymes.
\end{abstract}

(C) 2002 Elsevier Science B.V. All rights reserved.

Keywords: Platinum; Palladium; $\alpha$-Amino acid; Phosphonate

\section{Introduction}

The incorporation of organometallic complexes in large biomolecules requires the synthesis of small, stable and topologically predetermined organometallic units. In such building blocks, the metal is usually introduced at the end of the synthetic protocol, which normally involves several known organic transformations to attach the ligand moiety to its biological counterpart. Cross-coupling reactions, such as the Suzuki-Miyaura coupling reaction [1] between arylboron derivatives and alkyl halides or triflates catalyzed by palladium species, have shown to be powerful tools to incorporate aryl moieties in a large variety of molecules. Among these,

\footnotetext{
Presented at the First International Symposium on Bioorganometallic Chemistry, 18-20 July, 2002, Paris. Lecture: Biomolecules as Support for Metal 'Pincer' Complexes: Synthesis and Applications. Poster: Anchoring of ' $N C N$ ' Platinum Complexes to Proteins.

* Corresponding author. Tel.: +31-30-2533120; fax: +31-302523615

E-mail address: g.vankoten@chem.uu.nl (G. van Koten).
}

various biologically relevant molecules such as $\alpha$-amino acids [2], phosphonates [3], carbohydrates [4] and nucleosides [5] have been used as starting materials. The mild reaction conditions used, in principle, can help to preserve the enantiomeric purity of the starting biomolecule, which makes this an interesting approach to introduce any aryl moiety to the aforementioned molecules. Despite these facts, to the best of our knowledge, the Suzuki-Miyaura cross-coupling reaction has not been used to incorporate metal-binding ligands in such biomolecules which would enable the preparation of so-called 'bioorganometallic molecules'. In one case, the related Sonogashira cross-coupling reaction between terminal alkynyl derivatives and aryl halides or triflates catalyzed by copper-palladium species has recently been used for the attachment of possible coordination complexes, such as bypiridine and terpyridine-metal derivatives, onto $\alpha$-amino acids [6] with promising results. Recent studies demonstrated the great versatility of 1-bromo-4-iodo-2,6-bis[(dimethylamino)methyl]benzene (1, I-NCN-Br, Fig. 1) as a multidentate organometallic ligand in organic and organometallic chemistry [7]. 


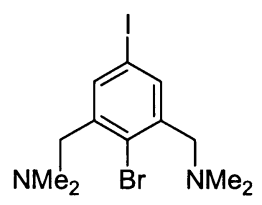

1

Fig. 1. Ligand precursor $\mathrm{I}-\mathrm{NCN}-\mathrm{Br}$.

Some of the transition metal complexes of such potentially terdentate, monoanionic ' $\mathrm{NCN}$ '-pincer ligands have a remarkable stability due to the presence of the bis ortho-chelation motif which makes the central $\sigma$ carbon-metal bond less sensitive towards electrophilic or nucleophilic attack [8]. In fact, this unusual high stability allowed us to perform various reaction protocols, which are commonly used for peptide chemistry. For example, we have prepared NCN-pincer platinu$\mathrm{m}$ (II) [9] and palladium(II) [10] complexes which were covalently bonded, via the para-C position, to either $N$ or $C$-termini of different natural $\alpha$-amino acids (Fig. 2). The resulting compounds are currently studied for applications as biomarkers and as homogeneous catalysts.

In this paper, we report the usefulness of the SuzukiMiyaura cross-coupling approach for the attachment of $\mathrm{NCN}$-pincer metal complexes to biologically relevant molecules such as $\alpha$-amino acids and phosphonates [11].

\section{Results and discussion}

The incorporation of an organometallic site at the $\alpha$ position of an $\alpha$-amino acid [12] would allow, after removal of the corresponding protective groups, the introduction of an organometallic site to any position of a peptidic chain. For this purpose, we have chosen the Suzuki-Miyaura cross-coupling reaction of the protected allyl glycine ester $\mathbf{2}$ [13] and the bifunctional precursor I-NCN-Br 1 (Scheme 1). The borane intermediate formed by reaction of 2 with 9-BBN (9borabicyclo[3.3.1]nonane) was reacted with 1 using $\left[\mathrm{PdCl}_{2}(\mathrm{dppf})\right]$ as catalyst. After $12 \mathrm{~h}$ reflux, the NCNbishomophenylalanine analog 3 was obtained in $72 \%$ yield. Metallation of $\mathbf{3}$ was carried out using $[\operatorname{Pt}(\mu-$ $\left.\left.\mathrm{SEt}_{2}\right)(p \text {-tol })_{2}\right]_{2}$, yielding the expected protected NCNpincer platinum(II) $\alpha$-amino acid 4 in $79 \%$ yield. Alternatively, the palladium(II) analog $\mathbf{5}$ was obtained

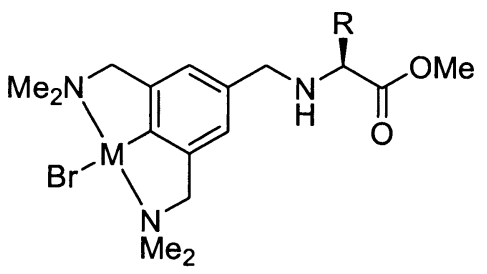

by oxidative addition of $\mathrm{Pd}_{2}(\mathrm{dba})_{3} \cdot \mathrm{CHCl}_{3}$ in $66 \%$ yield. Deprotection, i.e. hydrolysis, of the $\alpha$-labeled $\alpha$-amino acid 4 to the corresponding free $\alpha$-amino acid would enlarge the applicability of these bioorganometallic complexes in peptide chemistry [14]. Although most organometallic complexes do not tolerate basic or acidic conditions, NCN-pincer platinum halide complexes are stable enough to survive these conditions. Thus, the hydrolysis of $\mathbf{4}$ to the free $\alpha$-amino acid $\mathbf{8}$ was accomplished in two steps. First, the methyl esterprotecting group of $\mathbf{4}$ was hydrolyzed to the corresponding acid $\mathbf{6}$ (isolated in $77 \%$ yield) by treatment with lithium hydroxide in a $\mathrm{THF}-\mathrm{H}_{2} \mathrm{O}$ solution [15]. Using a similar method the methyl ester of the palladated compound $\mathbf{5}$ could be hydrolyzed to the free amino acid 7 in $46 \%$ yield. In the second stage, removal of the Bocprotecting group was achieved by treatment of $\mathbf{6}$ with $\mathrm{HBr}-\mathrm{Et}_{2} \mathrm{O}$, giving the free $\alpha$-platinum(II) labeled $\alpha$ amino acid $\mathbf{8}$ in $75 \%$ yield (Scheme 1).

Recently we also succeeded in extending the abovedescribed procedure for the attachment of NCN-pincer metal complexes to phosphonates. To this purpose, allyl $N, N$-dimethyl phosphonate 9 [16] was synthesized from commercial available diethylchlorophosphate in several steps. Compound 9 was reacted with $9-\mathrm{BBN}$ to generate a borane intermediate, which subsequently was coupled to $\mathrm{I}-\mathrm{NCN}-\mathrm{Br} \mathbf{1}$, using $\left[\mathrm{PdCl}_{2}\right.$ (dppf)] as catalyst. After 3 $\mathrm{h}$ reflux the phosphonate derivative $\mathbf{1 0}$ was obtained in $90 \%$ yield. Metallation of 10 using $\left[\mathrm{Pt}\left(\mu-\mathrm{SEt}_{2}\right)\left(p-\mathrm{tol}_{2}\right)_{2}\right]_{2}$ yielded the expected NCN-pincer platinum(II) substituted phosphonate 11 in $78 \%$ yield. By means of an oxidative addition of $\mathbf{1 0}$ with $\mathrm{Pd}_{2}(\mathrm{dba})_{3} \cdot \mathrm{CHCl}_{3}$, also the palladium(II) phosphonate analog 12 could be obtained in $73 \%$ yield (Scheme 2 ).

\section{Conclusions}

In summary, we have developed procedures allowing the successful attachment of the versatile $\mathrm{I}-\mathrm{NCN}-\mathrm{Br}$ ligand to $\alpha$-position of an $\alpha$-amino acid as well as to the terminal position ( $\gamma$-position in the case of $\mathbf{1 1}$ and 12) of the chain of an alkyl phosphonate. These derivatives can be directly metallated to give the platinum(II) or palladium(II) complexes in good to quantitative yields.

In our further research we are now using these bioorganometallics derivatives for different purposes.

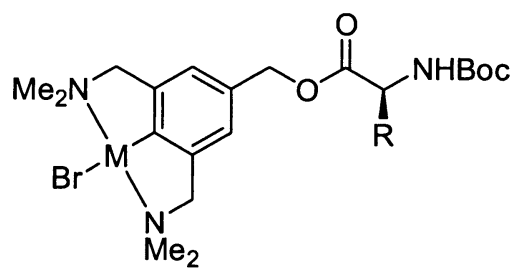

Fig. 2. $N$ - and $C$-metallated $\alpha$-amino acids $(\mathrm{M}=\mathrm{Pt}$ or $\mathrm{Pd})$. 
<smiles>CC#CCCC(=O)NC(CCCc1cc(CNC)c(Br)c(CN(C)C)c1)C(=O)OCc1ccccc1</smiles>

3

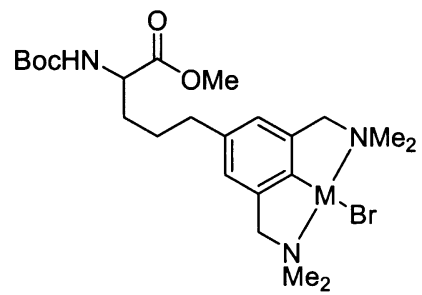

4, $M=P t, R=M e, R^{\prime}=B o c$

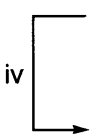

5, $M=P d, R=M e, R^{\prime}=B o c$

6, $M=P t, R=H, R^{\prime}=B o c$

7, $M=P d, R=H, R^{\prime}=B o c$

8, $M=P t, R=H, R^{\prime}=H_{3} B r$

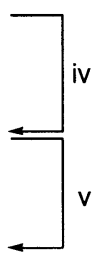

Scheme 1. Reagents and conditions. (i) 9-BBN, THF, 2 h r.t.; (ii) $\mathrm{K}_{3} \mathrm{PO}_{4}, \mathrm{DMF}, 10 \%\left[\mathrm{PdCl}_{2}(\mathrm{dppf})\right], \mathbf{1}, \Delta, 12 \mathrm{~h}$; (iii) $\left[\mathrm{Pt}\left(\mu-\mathrm{SEt}_{2}\right)(p \text {-tol })_{2}\right]_{2}$ or $\mathrm{Pd} \mathrm{d}_{2}(\mathrm{dba})_{3}$. $\mathrm{CHCl}_{3}, \mathrm{C}_{6} \mathrm{H}_{6}, 50{ }^{\circ} \mathrm{C}, 3 \mathrm{~h}$; (iv) $\mathrm{LiOH}, \mathrm{THF}-\mathrm{H}_{2} \mathrm{O}$, r.t., 12 h; (v) $\mathrm{HBr}-\mathrm{Et}_{2} \mathrm{O}$, r.t., 1 h.

The free organometallic amino acids $\mathbf{6 , 7}$ and 8 are currently included at various positions in the chains of polypeptides. In one example, the $\mathrm{NCN}$-pincer platinum complex acts as a color biomarker in combinatorial synthetic peptide libraries.

The $\gamma$-NCN-pincer platinum substituted allylphosphonate is highly interesting because phosphonates are commonly used as selective inhibitors of enzymes such as lipases [17]. The use of phosphonates of type $\mathbf{1 1}$ and 12 would allow the single-site directed incorporation of this bioorganometallic unit into a biomolecule of great complexity as an enzyme. In this way, interesting properties of such a biomolecule, e.g. water solubility, nano-size, chiral environment of the inhibited pocket, would be transferred to the organometallic site. Current studies already showed that a phosphonate derivative of $\mathbf{1 1}$ is an active inhibitor of the enzyme cutinase (from Fusarium solani pisi, [18]) and that the inhibited lipaseNCN-pincer construct can be isolated. Presently full characterization of this construct is underway.

\section{Experimental}

\subsection{General}

Suzuki and metallation reactions were carried out under nitrogen atmosphere using standard Schlenk techniques. THF and $\mathrm{C}_{6} \mathrm{H}_{6}$ were dried from $\mathrm{Na}-$ benzophenone and distilled prior to use. DMF was flash-distilled from $\mathrm{CaH}_{2}$ and stored on molecular sieves. The Pt salt $\left[\mathrm{Pt}\left(\mu-\mathrm{SEt}_{2}\right)\left(p-\mathrm{tol}_{2}\right)_{2}\right]_{2}[19]$, the ligand precursor [I-NCN-Br] 1 [7], and compounds 2 [13], 4 [9], 6 [9], 8 [9], 9 [16], 10 [16], 11 [16] were prepare according to published procedures. All other reagents were obtained commercially and used without further purification. The ${ }^{1} \mathrm{H}$ - and ${ }^{13} \mathrm{C}-\mathrm{NMR}$ spectra were recorded at 300 and $75 \mathrm{MHz}$, respectively, at $25^{\circ} \mathrm{C}$ and were referenced to external $\mathrm{SiMe}_{4}(\delta=0.00, J$ in $\mathrm{Hz}$ ). Elemental analyses were performed by Kolbe, Mikroanalytisches Laboratorium (Mülheim, Germany). MALDI-TOF-MS spectra were acquired using a Voyager-DE BioSpectrometry Workstation (PerSeptive Biosystems Inc., Framingham, MA) mass spectrometer equipped with a nitrogen laser emitting at $337 \mathrm{~nm}$. The instrument was operated in the linear mode at an accelerating voltage in the range $22000 \mathrm{~V}$. External calibration was performed using $\mathrm{C}_{60} / \mathrm{C}_{70}$, and detection was performed by means of a linear detector and digitizing oscilloscope operating at $500 \mathrm{MHz}$. Sample solutions with ca. $10 \mathrm{mg} \mathrm{ml}^{-1}$ in THF were used, and the matrix were 3,5-dihydroxybenzoic acid or 5-chlorosalycilic acid in THF $\left(10 \mathrm{mg} \mathrm{ml}^{-1}\right)$. A solution of silver(I) trifluoroacetate in THF was in some cases added to the sample in order to improve the peak resolution. The sample solution $(0.2 \mu \mathrm{l})$ and the matrix

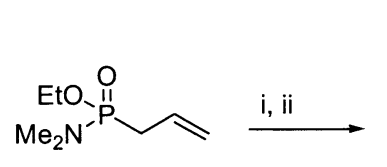

9

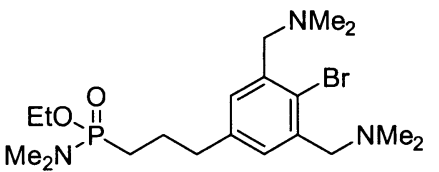

10

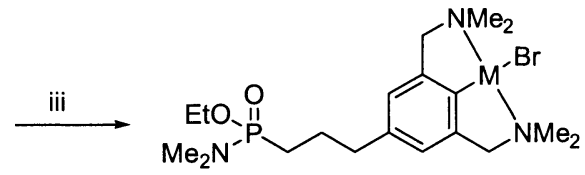

$$
\begin{aligned}
& 11, M=P t \\
& 12, M=P d
\end{aligned}
$$


solution $(0.2 \mu \mathrm{l})$ were combined and placed on a gold MALDI target and analyzed after evaporation of the solvents.

\subsection{Synthesis of compound 5}

A mixture of $3(187 \mathrm{mg}, 0.38 \mathrm{mmol})$ and $\left[\mathrm{Pd}_{2}(\mathrm{dba})_{3}\right.$. $\mathrm{CHCl}_{3}$ ] $(207 \mathrm{mg}, 0.20 \mathrm{mmol})$ in dry $\mathrm{C}_{6} \mathrm{H}_{6}(15 \mathrm{ml})$ was refluxed for $2 \mathrm{~h}$. After cooling to room temperature (r.t.) the reaction mixture was filtered over Celite and the volatiles were removed at reduced pressure. The resulting oil was purified by column chromatography $\left(\mathrm{SiO}_{2}\right)$ using as eluent $\mathrm{CH}_{2} \mathrm{Cl}_{2}$ until all dba came out of the column and then a mixture of $\mathrm{CH}_{2} \mathrm{Cl}_{2}$-acetone (1:1) was used. The palladium-containing fractions were collected and evaporated to dryness, yielding $\mathbf{5}$ as a yellow solid (150 mg, 66\%). ${ }^{1} \mathrm{H}-\mathrm{NMR}\left(\mathrm{CDCl}_{3}\right): \delta 1.38$ (s, 9H; $\left.\mathrm{OC}\left(\mathrm{CH}_{3}\right)_{3}\right), 1.53-1.76\left(\mathrm{~m}, 4 \mathrm{H} ; \mathrm{CH}_{2} \mathrm{CH}_{2}\right), 2.42-$ 2.48 (m, 2H; $\left.\mathrm{CH}_{2} \mathrm{CH}\right), 2.91$ (s, $\left.12 \mathrm{H} ; \mathrm{NCH}_{3}\right), 3.67$ (s, $3 \mathrm{H}$; $\left.\mathrm{OCH}_{3}\right), 3.91\left(\mathrm{~s}, 4 \mathrm{H} ; \mathrm{CH}_{2} \mathrm{NMe}_{2}\right), 4.24-4.26(\mathrm{~m}, 1 \mathrm{H}$; $\mathrm{NH}-\mathrm{C} H-\mathrm{CO}), 4.97\left(\mathrm{~d},{ }^{3} J_{\mathrm{HH}}=7.9,1 \mathrm{H} ; \mathrm{NH}\right), 6.53(\mathrm{~s}$, $2 \mathrm{H} ; \mathrm{ArH}) ;{ }^{13} \mathrm{C}-\mathrm{NMR}\left(\mathrm{CDCl}_{3}\right): \delta 27.3\left(\mathrm{CH}_{2} \mathrm{CH}_{2}\right), 28.1$ $\left(\mathrm{OC}\left(\mathrm{CH}_{3}\right)_{3}\right), \quad 32.2\left(\mathrm{CH}_{2} \mathrm{CH}_{2}\right), \quad 35.2\left(\mathrm{CH}_{2} \mathrm{CH}\right), \quad 52.1$ $\left(\mathrm{OCH}_{3}\right), \quad 53.1 \quad(\mathrm{NH}-\mathrm{CH}-\mathrm{CO}), \quad 53.5\left(\mathrm{NCH}_{3}\right), \quad 74.3$

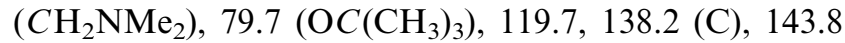
(C), $154.2(\mathrm{C}), 155.1 \quad(\mathrm{NHCO}), 173.1 \quad\left(\mathrm{CO}_{2}\right) ; \mathrm{MS}$ (MALDI-TOF): $\mathrm{m} / \mathrm{z} 524.6[\mathrm{M}-\mathrm{Br}]^{+}$(Calc. 526.2); Anal. Calc. for $\mathrm{C}_{23} \mathrm{H}_{39} \mathrm{BrN}_{3} \mathrm{O}_{4} \mathrm{Pd}$ (605.11): C, 45.52; H, 6.31; N, 6.92. Found: C, 45.68; H, 6.37; N, 6.86\%.

\subsection{Hydrolysis of 5. Synthesis of compound 7}

A solution of $5(100 \mathrm{mg}, 0.16 \mathrm{mmol})$ and $\mathrm{LiOH} \cdot \mathrm{H}_{2} \mathrm{O}$ (32 $\mathrm{mg}, 0.8 \mathrm{mmol}, 56 \%)$ in $\mathrm{THF}-\mathrm{H}_{2} \mathrm{O}(4: 1.5 \mathrm{ml})$ was stirred at r.t. overnight. The reaction mixture was subsequently treated with a $1 \mathrm{M} \mathrm{HCl}$ (aq.). The aqueous phase was extracted with EtOAc $(3 \times 20 \mathrm{ml})$ and the collective organic layer were washed with brine and dried over $\mathrm{MgSO}_{4}$ to afford 20 (40 mg, 42\%). ${ }^{1} \mathrm{H}-\mathrm{NMR}$ $\left(\mathrm{CD}_{3} \mathrm{OD}\right): \delta 1.37$ (s, 9H; OC( $\left.\left.\mathrm{CH}_{3}\right)_{3}\right), 1.59-1.81(\mathrm{~m}, 4 \mathrm{H}$; $\left.\mathrm{CH}_{2} \mathrm{CH}_{2}\right), 2.42-2.46\left(\mathrm{~m}, 2 \mathrm{H} ; \mathrm{CH}_{2} \mathrm{CH}\right), 2.89(\mathrm{~s}, 12 \mathrm{H}$; $\left.\mathrm{NCH}_{3}\right), 3.90\left(\mathrm{~s}, 4 \mathrm{H} ; \mathrm{CH}_{2} \mathrm{NMe}_{2}\right), 4.18-4.25(\mathrm{~m}, 1 \mathrm{H}$; $\mathrm{NH}-\mathrm{C} H-\mathrm{CO}), 5.15\left(\mathrm{~d},{ }^{3} J_{\mathrm{HH}}=8.0,1 \mathrm{H} ; \mathrm{NH}\right), 6.54(\mathrm{~s}$, $2 \mathrm{H} ; \mathrm{ArH}) ;{ }^{13} \mathrm{C}-\mathrm{NMR}\left(\mathrm{CDCl}_{3}\right): \delta 27.3\left(\mathrm{CH}_{2} \mathrm{CH}_{2}\right), 28.1$ $\left(\mathrm{OC}\left(\mathrm{CH}_{3}\right)_{3}\right), \quad 32.1 \quad\left(\mathrm{CH}_{2} \mathrm{CH}_{2}\right), \quad 35.3\left(\mathrm{CH}_{2} \mathrm{CH}\right), 53.4$ $\left(\mathrm{NCH}_{3}\right), 65.6(\mathrm{NH}-\mathrm{CH}-\mathrm{CO}), 74.2\left(\mathrm{CH}_{2} \mathrm{NMe}_{2}\right), 83.4$ $\left(\mathrm{OC}\left(\mathrm{CH}_{3}\right)_{3}\right), 119.7,138.3(\mathrm{C}), 144.8(\mathrm{C}), 145.3(\mathrm{C}), 155.5$ ( $\mathrm{NHCO}), 177.3\left(\mathrm{CO}_{2}\right)$.

\subsection{Synthesis of compound 11}

Solid $\left[\operatorname{Pt}\left(\mu-\mathrm{SEt}_{2}\right)(p \text {-tolyl })_{2}\right]_{2}(1.06 \mathrm{~g}, 1.14 \mathrm{mmol})$ was added to a solution of $\mathbf{1 0}(1.02 \mathrm{~g}, 2.27 \mathrm{mmol})$ in $(45 \mathrm{ml})$ $\mathrm{C}_{6} \mathrm{H}_{6}$ and heated to reflux for $1 \mathrm{~h}$. The solvent was removed and the remaining dark brown oil dissolved in (15 ml) $\mathrm{CH}_{2} \mathrm{Cl}_{2}$ and filtrated through a path of Celite.
The filtrate was concentrated under reduced pressure leaving a brown oil which was subsequently washed with $(3 \times 30 \mathrm{ml}$, stirring $30 \mathrm{~min}) \mathrm{C}_{5} \mathrm{H}_{12}$ and $(2 \times 30 \mathrm{ml}$, stirring $30 \mathrm{~min}$ ) $\mathrm{Et}_{2} \mathrm{O}$. The residue was dried in vacuo to obtain the product as an off-white solid $(1.11 \mathrm{~g}, 78 \%)$. ${ }^{1} \mathrm{H}-\mathrm{NMR}\left(\mathrm{C}_{6} \mathrm{D}_{6}\right): \delta 6.52(\mathrm{~s}, \mathrm{Ar} H, 2 \mathrm{H}), 3.91\left(\mathrm{~m}, \mathrm{CH}_{2} \mathrm{O}\right.$, $2 \mathrm{H}), 3.33\left(\mathrm{~s}, \mathrm{ArCH}_{2} \mathrm{~N},{ }^{3} J_{\mathrm{HPt}}=44.56 \mathrm{~Hz}, 4 \mathrm{H}\right), 2.77(\mathrm{~s}$, $\left.\mathrm{N}\left(\mathrm{CH}_{3}\right)_{2},{ }^{3} J_{\mathrm{HPt}}=37.54 \mathrm{~Hz}, 12 \mathrm{H}\right), 2.60\left(\mathrm{t}, \mathrm{CH}_{2} \mathrm{Ar}\right.$, $\left.{ }^{3} J_{\mathrm{HH}}=7.32 \mathrm{~Hz}, 4 \mathrm{H}\right), 2.43\left(\mathrm{~d}, \mathrm{PN}\left(\mathrm{CH}_{3}\right)_{2},{ }^{3} J_{\mathrm{HP}}=8.85\right.$ $\mathrm{Hz}, 6 \mathrm{H}), 2.02\left(\mathrm{~m}, \mathrm{CH}_{2}, 2 \mathrm{H}\right), 1.71\left(\mathrm{t}, \mathrm{CH}_{2},{ }^{3} \mathrm{~J}_{\mathrm{HH}}=7.63\right.$ $\mathrm{Hz}, 2 \mathrm{H}), 1.06\left(\mathrm{t}, \mathrm{CH}_{3} \mathrm{CH}_{2} \mathrm{O},{ }^{3} J_{\mathrm{HH}}=7.02 \mathrm{~Hz}, 3 \mathrm{H}\right) .{ }^{31} \mathrm{P}-$ NMR $\left(\mathrm{C}_{6} \mathrm{D}_{6}\right): \delta 36.26$ (s). ${ }^{13} \mathrm{C}-\mathrm{NMR}(75.468 \mathrm{MHz}$, $\left.\mathrm{C}_{6} \mathrm{D}_{6}\right): \delta 145.52,136.38,134.52,119.54$ (s, $\left.\operatorname{ArC}\right), 77.13$ $\left(\mathrm{s},{ }^{2} J_{\mathrm{CPt}}=32.96 \mathrm{~Hz}, \mathrm{ArCH}_{2} \mathrm{~N}\right), 58.82\left(\mathrm{~d}, \mathrm{CH}_{2} \mathrm{O},{ }^{2} J_{\mathrm{CP}}=\right.$ $7.33 \mathrm{~Hz}), \quad 54.62\left(\mathrm{~s}, \mathrm{~N}\left(\mathrm{CH}_{3}\right)_{2}\right), 37.44\left(\mathrm{~d}, \mathrm{CH}_{2} \mathrm{CH}_{2} \mathrm{P}\right.$, $\left.{ }^{2} J_{\mathrm{CP}}=14.65 \mathrm{~Hz}\right), 35.81\left(\mathrm{~d}, \mathrm{PN}(\mathrm{CH})_{3},{ }^{2} J_{\mathrm{CP}}=4.27 \mathrm{~Hz}\right)$, $25.33\left(\mathrm{~d}, \mathrm{CH}_{2} \mathrm{P},{ }^{1} J_{\mathrm{CP}}=130.62 \mathrm{~Hz}\right), 16.65\left(\mathrm{~d}, \mathrm{CH}_{3} \mathrm{CH}_{2} \mathrm{O}\right.$, ${ }^{3} J_{\mathrm{CP}}=5.49 \mathrm{~Hz}$ ); MS (MALDI-TOF, CSA): $\mathrm{m} / \mathrm{z}: 561.1$ $[\mathrm{M}-\mathrm{Br}]^{+}, 467.2[\mathrm{M}-\mathrm{Br}-\mathrm{Pt}]^{+}$; Anal. Calc. for $\mathrm{C}_{7} \mathrm{H}_{16} \mathrm{NO}_{2} \mathrm{P}: \mathrm{C}, 42.30 ; \mathrm{H}, 9.42 ; \mathrm{N}, 6.69$. Found: $\mathrm{C}$, 42.48; H, 9.36; N, 6.76\%.

\section{Acknowledgements}

G.G. is a Marie Curie fellow and thanks the European Commission for a IHP Grant (Contract No. HPMF-CT-2000-00472). This work was supported by the Council for Chemical Sciences of the Dutch Organization for Scientific Research (CW-NWO).

\section{References}

[1] (a) A. Suzuki, J. Organomet. Chem. 576 (1999) 147; (b) N. Miyaura, A. Suzuki, Chem. Rev. 95 (1995) 2457.

[2] (a) P.N. Collier, A.D. Campbell, T.M. Patel, T.M. Raynham, R.J.K. Taylor, J. Org. Chem. 67 (2002) 2121;

(b) M. Isaac, A. Slassi, K. Da Silva, T. Xin, Tetrahedron Lett. 42 (2001) 2957;

(c) S. Collet, R. Danion-Bougot, D. Danion, Synth. Commun. 31 (2001) 249;

(d) F. Firooznia, C. Gude, K. Chan, N. Narcopulos, Y. Satoh, Tetrahedron Lett. 40 (1999) 213.

[3] I. Pergament, M. Srebnik, Org. Lett. 3 (2001) 217.

[4] (a) C.R. Johnson, B.A. Johns, Tetrahedron Lett. 38 (1997) 7977; (b) C.R. Johnson, B.A. Johns, Synlett (1997) 1406.

[5] (a) N. Amann, H.A. Wagenknecht, Synlett (2002) 687; (b) M.K. Lakshman, J.H. Hillmer, J.Q. Martin, J.C. keeler, Y.Q.V. Dinh, F.N. Ngassa, L.M. Russon, J. Am. Chem. Soc. 123 (2001) 7779;

(c) M. Hocek, A. Holy, I. Votruba, H. Dvorakova, J. Med. Chem. 43 (2000) 1817.

[6] A. Khatyr, R. Ziessel, Org. Lett. 3 (2001) 1857.

[7] G. Rodríguez, M. Albrecht, J. Schoenmaker, A. Ford, M. Lutz, A.L. Spek, G. van Koten, J. Am. Chem. Soc. 124 (2002) 5127.

[8] (a) M. Albrecht, G. van Koten, Angew. Chem. Int. Ed. Engl. 40 (2001) 3750;

(b) M.H.P. Rietveld, D.M. Grove, G. van Koten, New J. Chem. 21 (1997) 751. 
[9] (a) G. Guillena, G. Rodríguez, M. Albrecht, G. van Koten, Chem. Eur. J. (2002) 5368;

(b) M. Albrecht, G. Rodríguez, J. Schoenmaker, G. van Koten, Org. Lett. 2 (2000) 3461.

[10] G. Guillena, G. Rodríguez, G. van Koten, Tetrahedron Lett. 43 (2002) 3895

[11] (a) P. Kielbansinki, J. Omalanczuk, M. Mikolajczyk, Tetrahedron: Asymmetry 9 (1998) 3283;

(b) C.D.S. Tomlin, The Pesticide Manual, British Crop protection Council, Farnham, Surrey, UK, 1997.

[12] R.M. Williams, Advances in Asymmetric Synthesis, vol. 1, Jai Press, Greenwich, 1995, p. 45.

[13] S. Collet, R. Danion-Bougot, D. Danion, Tetrahedron: Asymmetry 9 (1998) 2121.

[14] Gabriela Guillena, Koen Halkes, Gema Rodríguez, Gerard van Koten, Johannis P. Kamerling, manuscript in preparation.
[15] W. Oppoltzer, P. Lienard, Helv. Chim. Acta 75 (1992) 2572.

[16] C.A. Kruithof, M.A. Casado, G. Guillena, M.A. Egmond, G. van Koten, manuscript in preparation.

[17] (a) F. Björkling, A. Dahl, S. Patkar, M. Zundel, Bioorg. Med. Chem. 2 (1994) 697;

(b) P.E. Kolattukudy, Lipases, Elsevier, Amsterdam, 1984, pp. 471-501.

[18] (a) K. Faber, Biotransformations in Organic Chemistry, SpringerVerlag, Berlin-Heildeberg, 2000, p. 453;

(b) C. Martínez, P. Geus, M. Lauwereys, M. Matthyssens, C. Cambillau, Nature 356 (1992) 615.

[19] (a) B.R. Steele, K. Vrieze, Transition Met. Chem. 2 (1977) 140

(b) A.J. Canty, J. Patel, B.W. Skelton, A.H. White, J. Organomet. Chem. 599 (2000) 195 